\title{
Sobre fotografía, memoria y barbarie: el conflicto que no vimos ni vivimos
}

Sergio Roncallo-Dow ${ }^{1}$

DOI: 10.5294/pacla.2020.23.2.9

Para citar esta reseña / To cite this review / Para citar esta resenha

Roncallo-Dow, S. (2020). Sobre fotografía, memoria y barbarie: el conflicto que no vimos ni vivimos. Palabra Clave, 23(2), e2329. https://doi.org/10.5294/pacla.2020.23.2.9

Reseña de libro: Bonilla Vélez, Jorge Iván (2019).

La barbarie que no vimos: fotografía y memoria en Colombia. Medellín, Colombia: Editorial EAFIT. ISBN: 978-958-720-607-4, 436 páginas.

Todos los hombres desean por naturaleza saber. Así lo indica el amor a los sentidos; pues, al margen de su utilidad, son amados a causa de sí mismos, y el que más de todos, el de la vista. En efecto, no sólo para obrar, sino también cuando no pensamos hacer nada, preferimos la vista, por decirlo así, a todos los otros. Y la causa es que, de los sentidos, éste es el que nos hace conocer más, y nos muestra muchas diferencias. (Aristóteles, Metafísica, 980a)

Muchas veces las imágenes son motivo de estupefacción. Esto, en particular, porque cuando nos acercamos a ellas tendemos a ver una reconstrucción de algo que las preexiste y les asignamos una condición ontológica que, si antes rayaba en la idea platónica de lo irreal y luego pasó por el tamiz de los simulacros, hoy entra en el cómodo resguardo epistemológico del escándalo y la hipervisibilidad. Pero las imágenes son mucho más que eso, son un lugar que tiene una condición de enunciación propia y que, lejos de estar ancladas de forma subsidiaria a una realidad que las sostiene, son capaces de producir justamente lo que es inimaginable. Quizá, de todas las formas que puede asumir la imagen, la fotografía sea el modo en que esta

$1 \bowtie$ https://orcid.org/0000-0002-9816-1288. Universidad de La Sabana, Colombia. sergiord@unisabana.edu.co 
haya desplegado mejor su potencia en nuestro presente y nos haya dado la posibilidad de pensar lo que significa ver. Esta es la premisa con la que vale la pena abordar el trabajo de Bonilla Vélez (2019), La barbarie que no vimos: fotografía y memoria en Colombia.

Se trata de un libro que es, ante todo, un deber con la historia y con la ética. Pero no se trata de dos conceptos que se puedan pensar de manera genérica. Bonilla Vélez emprende un viaje que aborda el problema del conflicto armado en Colombia y sus modos de representación fotográfica que se traducen en formas de reconocimiento y desconocimiento de los actores que dieron forma a lo que, retomando un viejo artículo de la revista $\mathrm{Se}$ mana, el autor llama la "barbarie".

Más allá de la erudición con la que es escrito este libro, su mayor valor radica en que plantea una incomodidad que resulta más que necesaria en medio de una realidad mediática que ha sido poco menos que complaciente con el problema del conflicto, en medio de una época en la que hay voces que, incluso, pretenden negar su existencia. La recuperación de la fotografía como un lugar que a su vez genera un conflicto intrínseco, el de la representación y los regímenes de visibilidad, recuerda inmediatamente las reflexiones de pensadores tan potentes como Rancière (quien es uno de los guías de este libro) en la medida en que pone sobre la mesa la multiplicidad y las contradicciones inherentes a los regímenes de representación y las formas políticas que subyacen la imagen y que trascienden, por mucho, el mero problema de lo que se muestra.

El trabajo aborda uno de los periodos más sangrientos de la historia reciente de Colombia, el comprendido entre finales de la década de 1980 y la primera década del siglo XXI. Por supuesto, aunque ha habido muchos momentos en los que la barbarie ha sido el denominador común de nuestra cotidianidad, aquí el problema que emerge es el de las formas de mediatización del conflicto y la construcción de lo que el autor llama las políticas del encuadre ancladas a las pretensiones de los medios para poner en escena la realidad y, por supuesto, construir marcos de interpretación. De ahí que la pregunta que jalona el trabajo sea “iDe qué manera la fotografía de 
prensa ha dado inteligibilidad a la atrocidad y el sufrimiento, alentando esferas públicas de deliberación y promoviendo implicaciones éticas y morales sobre los horrores de la guerra en Colombia?” (p. 18).

Como lector del libro de Bonilla Vélez, creo que una de sus potencias es que logra establecer un diálogo muy fructífero entre lo que la fotografía muestra y lo que oculta. Es decir, hay un momento en el que la imagen, aparentemente objetiva y reducida a su condición subsidiaria de "documento periodístico", falla. En el fallo se produce el efecto de lo inimaginable que es solo posible a través de la imagen. Así, la memoria que producen las imágenes es una memoria que lleva implícito el fallo en la medida en que se trata de una narración en la que la intencionalidad pretendida puede revertir en su imagen especular. En el diálogo mostrar/ocultar, se esconde toda la potencia de la fotografía y allí yace su posibilidad de producir memoria, una que ya no es de archivo, sino una memoria del devenir. Es justo esto lo que está implícito en el método que utiliza Bonilla Vélez y que desde Mieke Bal y Georges Didi-Huberman busca trascender el problema de la intención y el efecto inmediato, tan comunes en las teorías de la comunicación, para restituir a la fotografía su carácter de dispositivo de producción de acontecimientos. De ahí que, como lo recuerda el autor, ver es comprender.

Se trata, entonces, de un libro con un compromiso amplio en la medida en que, a partir de un problema aparentemente muy trabajado como el de la representación del conflicto en la prensa, logra articular dinámicas más de fondo que permiten pensar la dimensión estética del conflicto y, consecuentemente, su dimensión política. Pero el deber de este libro aparece cuando busca levantar las piedras que ocultan los regímenes de visibilidad y pone en duda todo juego de verdad previamente agenciado por las intenciones del poder para dar paso a la potencia y la posibilidad que laten en las imágenes de una barbarie que no vimos ni vivimos.

\section{Referencias}

Bonilla Vélez, J. I. (2019). La barbarie que no vimos: fotografía y memoria en Colombia. Medellín, Colombia: Universidad EAFIT. 